\title{
IMMATURE NORTH AMERICAN TRICHOPTERA
}

\author{
By Margery J. Milne \\ Randolph-Macon Woman's College, \\ Lynchburg, Va.
}

Several keys to the larvæ and two to the pupæ of North American Trichoptera are already available ${ }^{1}$ but none of them summarizes recent study of adequate material, and all but one are based either directly or indirectly on tables presented by European workers.

A search for family and subfamily characters in North American caddis larvæ and pupæ has yielded the two keys below. Since the pupal stage is much less completely known than the larval, the key to the former is more artificial than that to the latter, especially with respect to members of the families Odontoceridæ and Sericostomatidæ. To somewhat offset this disadvantage, a very useful list of spur formulæ is appended, summarizing the known information on this character.

11901. Betten, C. in Bull. 47, N. Y. State Mus. pp. 563-564. A larval key compiled from European papers by Klapalek and Struck.

1915. Krafka, J. Jr. in Can. Ent. 46: 217-225. Original keys to larvae, guided by Ulmer's 1909 European work.

1921. Lloyd, J. T. in Bull. 21, Lloyd Lib. (Ent. Ser. 1) p. 15. A slightly modified translation of Ulmer's $1909 \mathrm{key}$, larvae only.

1921. Lutz, F. E. in Field Book of Insects (Putnam) pp. 58-60. A modification of Betten's 1901 key to larvae.

1925. Comstock, J. H. in Introduction to Entomology (Comstock) p. 560. A modification of Lloyd's 1921 key to larvae.

1926. Essig, E. O. in Insects of Western North America (Macmillan) p. 175. A modification of the key to larvae in Lloyd 1921 and Comstock 1925.

1926. Sibley, C. K. in Bull. 27, Lloyd Lib. (Ent. Ser. 5). An apparently original key to the pupae of species found on the LloydCornell Reservation, N. Y.

1933. Brues, C. T. \& A. L. Melander in Bull. 73, Mus. Comp. Zool. Harvard, pp. 195-197. A modification of Krafka's $1915 \mathrm{key}$ to larvae.

1934. Betten, C. in Bull. 292, N. Y. State Mus. pp. 117-123, the larval key a copy of Krafka's 1915 work, the pupal key from Ulmer's 1909 key. 
Caddis larvæ inhabiting movable cases have the head bent downward so that the mandibles are ventral (hypognathous) in position, the long axis of the head at an obtuse or even a right angle with the long axis of the body. Those with a right-angled attachment are said to be eruciform larvæ, those with an obtuse angle to be suberuciform. Caseless larvæ have the long axis of the head in line with the long axis of the body and the jaws hence at the anterior end of the animal (prognathous). Such larvæ are said to be thysanuriform or campodeiform.

Case-bearing larvæ frequently have fleshy tubercles on the sides and notum of the first abdominal segment. These are called spacing humps, and serve to keep a passage for respiratory water between the larva and its case. Such larvæ also often have a prominent projection from the prosternum, extending between the front coxæ. This is the prosternal horn or prosternal spine.

The head capsule or epicranium splits at ecdysis into right and left halves. It bears the articulating surfaces for the mandibles antero-laterally and may or may not meet on the mid-line ventrally, anterior to the neck opening (occipital foramen). In some forms a submentum or gula is well developed, the gula being sometimes quadrate, at other times triangular or crescentic. It may keep the epicranial halves entirely apart, extending from the labium to the occipital foramen, or it may separate them only anteriorly, so that the foramen is entirely surrounded by epicranium. A U- or $\mathrm{V}$-shaped emargination in the anterior margin of the epicranium on the mid-dorsal line accommodates the frons to which the labrum is attached by a flexible membrane. There is no clypeus. The antennae are usually very small.

Many larvæ have a fringe of hairs along the abdominal lateral line, the so-called "lateral fringe." The abdomen frequently bears along the dorsal, lateral and ventral surfaces filamentous or branched structures called gills, although their respiratory function is doubtful. Around the anus filamentous or sac-like structures are often seen. These are the rectal gills, which are seemingly retractible into the rectum. Also apical on the abdomen are the prolegs, fleshy structures with claws, used in locomotion. The thoracic appendages are true legs, and consist of five segments, a 
large coxa articulating with the pleurite, a small trochanter (always indistinctly divided), a large femur, a tibia, and a one-segmented tarsus bearing a movable claw. Usually the tibia ends in a spur. In Leptoceridæ and some Odontoceridæ, the middle and hind legs have the femora divided into two, the proximal half shorter than, or equalling the distal half.

In the pupæ imaginal structures such as antennæ, maxillary and labial palpi, ocelli, tibial spurs, sternal ligulæ and genitalia may be studied, in addition to the labral bristles, gills and anal processes of the pupal skin itself. All females have the maxillary palpi 5 -segmented, but the males of some families show a reduction in this number. In some families in which both sexes have 5-segmented maxillary palpi, the terminal segment is secondarily annulated. Labial palpi are always 3-segmented. There are 3 ocelli present or none are found. The fore tibiæ may have as many as 3 spurs, the middle and hind tibiæ as many as 4 spurs. When no more than 2 spurs are present, they are terminal. A third or fourth spur is added part way up the tibia. The number of spurs is indicated by a spur formula. Thus 1-3-4 indicates that the fore tibia bears one (terminal) spur, the middle tibia a pair of terminal and a subapical spur(s), the hind tibia a pair of terminal and a pair of subapical spurs. The labral bristles are used to clean the gratings which allow entrance of water into the pupal case. The gills are much like those of the larva but often differ in number and arrangement. The anal processes are extensions of the pupal skin which cover the cerci and genitalia and often bear bristles for cleaning the grating which allows exit of water from the pupal case.

\section{Key to North American Caddis LaRvae}

1. Abdomen very much wider than thorax; very minute species with all three thoracic segments heavily sclerotized above, living in portable silken cases which are much larger than the larvæ: Hydroptilidæ Abdomen not much wider than thorax; much larger species, never with all three thoracic nota heavily sclerotized above in any case-bearing species, the cases when present not much larger than the larvæ 2 
2. Last abdominal segment never with a sclerotized shield above; body campodeiform, the head held straight forward, forming a continuation of the long axis of the body; abdomen of nine segments, the prolegs distinct from one another; no tubercle on first abdominal segment; no prosternal horn; no lateral line fringe; abdomen depressed, the sutures between the segments deeply impressed; gills usually absent; rectal gill structures generally present but not always everted; larvæ not constructing a movable case

Last abdominal segment usually with a sclerotized shield above-if lacking it, the body eruciform (hypognathous) and the larva living in a movable case (Leptoceridæ); gills usually present

3. Labrum soft, whitish, retractile under edge of frons 4

Labrum wholly sclerotized ...................................... 5

4. Mandible with a prominent tooth at middle of medial margin; frons with a deep asymmetric emargination: .......... Philopotamidæ, subfamily Chimarrhinæ

Mandible with no such prominent tooth; frons scarcely emarginate:

Philopotamidæx, subfamily Philopotaminæ

5. Claws of legs long and slender, nearly straight, with only one basal spur; penultimate segment of maxillary palpus very long:

Psychomyiidæ, subfamily Polycentropodinæ

Claws of legs short, stout, curved; penultimate segment of maxillary palpi not especially long

6. Gills absent; only two bristles on convex side of mandibles

Gills present; numerous bristles on convex outer side of mandibles; all three thoracic nota sclerotized .... 8

7. Only prothorax sclerotized dorsally:

Psychomyiidæ, subfamily Psychomyiinæ All three thoracic nota sclerotized:

Psychomyiidæ, subfamily Ecnominæ

8. Gula an elongate, rectangular plate separating epicranial halves completely; all gill filaments in clus- 
ters arising from the ends of stalks, somewhat like the tentacles of Hydra; large forms:

Hydropsychidæ, subfamily Arctopsychinæ

Gula triangular, never reaching hind margin of head, the epicranial halves contiguous for some distance; gill filaments arising from the side as well as the end of the stalk, more comb-like

9. Dorsal surface of head flattened, forming a broad disc, enclosed by a strong carina which crosses the frons near its apex, setting off a small triangle; mandibles with broad, blunt teeth on whole inner margin, the interspaces broad and deep:

Hydropsychidæ, subfamily Macronematinæ

Dorsal surface of the head flattened, but with no carina defining its limits; mandibles with sharp teeth apically : .... Hydropsychidæ, subfamily Hydropsychinæ

10. Body campodeiform, the abdomen depressed; larvæ never constructing a movable case though sometimes building a fixed shelter

Body eruciform or suberuciform, the head bent downwards at an angle to the rest of the body; abdomen cylindrical, the sutures between the segments usually feebly impressed; gills usually present; larvæ always living in a movable, tubular shelter

11. Prolegs very well developed, entirely separate from each other; proleg claws long and slender, without teeth on convex surface; accessory claws sometimes present at sides of main proleg claws; maxillary lobes long and slender:

Rhyacophilidx, subfamily Rhyacophilinæ

Prolegs short, the basal segments wholly sclerotized and fused to the ninth abdominal segment in a nearly vertical position; proleg claws very short, with small teeth on the convex side; maxillary lobes short and broad; construction of a fixed shelter in late larval life is usual:

Rhyacophilidæ, subfamily Glossosomatinæ

12. Prosternum with a horn or spine projecting downwards between the front coxæ 
No such prosternal horn

13. Body suberuciform; lateral gills on segments 2 to 7 usually pubescent with black hairs; mesonotum generally soft like metanotum, rarely with two small sclerotized plates; abdominal constrictions well marked :

Phryganeidæ

Body eruciform; lateral gills on segments 2 to 7 never pubescent with black hairs; mesonotum generally entirely sclerotized, sometimes only with small plates, rarely completely soft

14. Mesonotum entirely sclerotized; metanotum with three pairs of plates; mesothoracic legs stouter and longer than hind legs:

Limnephilidæ

Mesonotum not entirely sclerotized; metanotum usually entirely soft; middle legs not longer than hind legs: A few Sericostomatidæ (Goerinæ\& Lepidostomatinæ)

15. Femora of middle and hind legs divided into a shorter basal and a longer apical piece; right mandibles without inner bristles; no accessory bristles on back of mandibles:

Femora not divided ..............................................17

16. Lateral line well developed ......................................17

Lateral line little developed or absent: ..... Leptoceridæ

17. Lateral line well developed, the 8 th segment never with only sclerotized points representing the line; labrum with a transverse row of many stout bristles before the middle, or if lacking these, then much longer than broad:

Odontoceridæ

Lateral line very faint, incomplete or absent, its place sometimes occupied on some segments by sclerotized points; labrum neither with a transverse row of bristles nor longer than broad

18. Antennæ rudimentary; pronotum sclerotized, mesonotum never more than partially sclerotized:

Sericostomatidx

Antennæ large, the basal segment broad, 2nd more slender and tipped with a fine bristle; pro- and mesonotum both sclerotized 
19. Distal spurs of fore and middle tibiæ not on prominences; hind legs with normal claws; cases curved tubes, never broad: Beræidæ

Distal spurs of fore and middle tibiæ on prominences; claws of hind legs abnormal; cases of sand, broadly shield-shaped like a turtle shell, except those of very young larvæ which have straight sand tubes, often with bits of mollusk shells : Molannidæ

\section{Key to North American Caddis Pupae}

1. Pupæ very small (not more than $5 \mathrm{~mm}$. long, usually less than $3.5 \mathrm{~mm}$.), with very short thick antennæ; maxillary palpi 5-segmented in both sexes; cases mostly of silk only or of silk covered with very fine sand, the cases flat or thickest in the middle, usually attached at each end by circular discs of silk:

\section{Hydroptilidx}

Pupæ usually larger, the antennæ nearly as long as the body, not especially thickened; maxillary palpi sometimes 3- or 4-segmented in the male; cases never as above

2. Lacking both ocelli and a complete tubular case ....... 3 Either ocelli or a complete tubular case or both present

3. Gills absent:

Psychomyiidæ, subfamily Psychomyiinæ

Gills present

4. Spurs 3-4-4 ; anal processes large, blunt, not long; cases made of pieces of leaves or small sand grains, the ventral side of silk only (in Phylocentropus the case is a long, branched tube of sand with only a turret projecting; in Neureclipsis the case is a trumpetshaped net) ;

Psychomyiidæ, subfamily Polycentropodinæ

Spurs 2-4-4 or fore tibiæ with one or no spur; anal processes long and heavily sclerotized, with many bristles:

Hydropsychidæ

5. Case complete, the pupa never in an inner silken cocoon; gills often present; anal processes often long, 
rod-like and strongly sclerotized; legs with or without claws

Case incomplete, the pupa in an inner silken cocoon; gills absent; no long or rod-like or strongly sclerotized anal processes; legs with good claws

6. Inner silken cocoon spindle-shaped like a zeppelin or a fly puparium, attached to the case only at its posterior end; case barn-shaped, usually of pebbles; 5 th segment of maxillary palpi not annulated

Inner silken cocoon either not complete or fused to case wall near its equator; when incomplete, the anterior end lacking, the posterior end much as in Rhyacophilinæ; 5th segment of maxillary palpi long, curved and distinctly annulated

7. Spurs 2-4-4: Rhyacophilidæ, subfamilies Glossosomatinæ \& Hydrobiosinæ Spurs 3-4-4: Rhyacophilidæ, subfamily Rhyacophilinæ

8. Spurs 2-4-4: Philopotamidæx, subfamily Philopotaminæ Spurs 1-4-4: Philopotamidæx, subfamily Chimarrhinæ

9. Ocelli present ....................................................10

Ocelli absent ........................................................... 12

10. Posterior margin of 1 st abdominal tergite produced caudad in a distinct median process extending over base of 2nd segment; mandibles with a prominence from which the bristles arise; anal processes flat, somewhat rhombic, with 4 long bristles at the end; spurs 2-4-4; male maxillary palpi 4-segmented:

Phryganeidæ

Posterior margin of 1st abdominal tergite not produced caudad but with a saddle-shaped prominence, laterally with short spines or with only two lateral tubercles set with numerous hairs or denticles; mandibles with no such prominence; never more than one protibial spur; male maxillary palpi 3-segmented; anal processes long, more slender

11. Labrum semicircular, anteriorly emarginate, the dorsal surface elevated, with a transverse furrow back of its mid line; spurs 1-1-1, 1-2-2, 1-2-3, 1-2-4, 1-3-3 or in most, 1-3-4: Limnephilidx 
Labrum roughly rectangular, the anterior margin formed of 3 curves, in each of the two emarginations of which is a fine bristle; 5 longer bristles with curved tips vertically on either side of labrum; spurs 1-2-4 (Pharula) or 1-3-4 (Neothremma) :

Sericostomatid $\mathscr{x}$, subfamily Georinæ in part

12. Antennæ very long, the outer part wound around the abdominal apex

Antennæ scarcely longer than body, the ends never wound as above ...................................................14

13. Two mesotibial spurs; mouthparts so placed that the pupal mandibles point upwards: Leptoceridæ

Four mesotibial spurs; mouthparts normal or as above: some Odontoceridæ

14. Spurs 2-2-2 (Micrasema) or 2-3-2 or 2-3-3 (Brachycentrus); labrum obtusely triangular to semicircular; maxillary palpi shorter than or but little longer than labial palpi, never stouter:

Sericostomatidx, subfamily Brachycentrinæ

Spurs not as above

15. Case shaped like a snail shell, coiled in a flat spiral, made of sand grains of small size:

Sericostomatidæ, subfamily Helicopsychinæ

Case never of this form

16. Less than four mesotibial spurs ..............................17

Four mesotibial spurs .............................................. 18

17. Body length not less than $5 \mathrm{~mm}$.; robust species :

Sericostomatidæ, subfamily Sericostomatinæ

Body length not over $4 \mathrm{~mm}$.; slender, small species:

Beræidæ

18. Less than 4 metatibial spurs: ....... some Odontoceridæ

Four metatibial spurs, the formula 2-4-4

19. Anal processes lobate:

Sericostomatidæ, subfamily Lepidostomatinæ

Anal processes rod-like

20. Case of sand, flattened dorso-ventrally and with lateral flanges, closed by discs of silk at the ends, that at the posterior end having a vertical slit, that at the anterior end a horizontal slit: Molannidx 
Case not as above, and differently closed

21. Case of stones with ballast rocks at the side, straight, never curved:

Sericostomatidæ, subfamily Goerinæ in part

Not as above; case with a definite curvature:

some Odontoceridæ

In families Hydropsychidæ (with subfamilies Hydropsychinæ, Arctopsychinæ and Macronematinæ), Psychomyiidæ (with subfamilies Psychomyiinæ, Polycentropodinæ and Ecnominæ) and Philopotamidæ (with subfamilies Philopotaminæ and Chimarrhinæ), the 5th segment of the maxillary palpi is secondarily segmented in the pupa and adult. In Leptoceridæ it is long and slender and often curved but never segmented. In males of Phryganeidæ, the fifth segment is lacking, so that the maxillary palpi are 4-segmented; in males of Limnephilidæ (with subfamilies Apataniinæ and Limnephilinæ) and Sericostomatidæ (with subfamilies Brachycentrinæ, Helicopsychinæ, Lepidostomatinæ, Goerinæ and Sericostomatinæ) the 4th and 5th segments are lacking so that the palpi are 3-segmented. The females of these families and both sexes of families Hydroptilidæ, Rhyacophilidæ (with subfamilies Rhyacophilinæ, Hydrobiosinæ, Glossosomatinæ), Beræidæ, Molannidæ and Odontoceridæ (with subfamilies Odontocerinæ and Calamoceratinæ) have five segments to the maxillary palpi. In all Limnephilidæ, Philopotamidæ, Phryganeidæ, Rhyacophilidæ, two genera of Sericostomatidæ (Thremma and Neothremma of Goerinæ), and in six genera of Hydroptilidæ (Agraylea, Allotrichia, Ithytrichia, Neotrichia, Oxyethira, and Polytrichia) there are ocelli, but elsewhere they are lacking.

Spur Formulae of North American Trichoptera

\begin{tabular}{|c|c|c|}
\hline Formula & Family & Genera Concerned \\
\hline $0-2-2$ & Leptoceridæ & $\begin{array}{l}\text { Leptocella, Leptocerus, Setodina, } \\
\text { Ymymia }\end{array}$ \\
\hline $0-2-3$ & Hydroptilidæ & Neotrichia \\
\hline $0-2-4$ & Hydroptilidæ & Hydroptila \\
\hline $0-3-4$ & Hydroptilidæ & $\begin{array}{l}\text { Agraylea, Allotrichia, Ithytrichia, Ortho- } \\
\text { trichia and Polytrichia }\end{array}$ \\
\hline
\end{tabular}




\begin{tabular}{|c|c|c|}
\hline Formula & Family & Genera Concerned \\
\hline \multirow[t]{2}{*}{$0-4-4$} & Hydropsychidæ & sometimes Hydropsyche \\
\hline & Rhyacophilidæ & Protoptila \\
\hline $1-1-1$ & Limnephilidæ & Glyphopsyche (areolatus) \\
\hline \multirow[t]{2}{*}{$1-2-2$} & Leptoceridæ & Ecetis, Triaenodes, Ylodes \\
\hline & Limnephilidæ & $\begin{array}{l}\text { Apatidea (nigra), Chilostigma, Glypho- } \\
\text { psyche (bellus, canadensis, irroratus, } \\
\text { pritus), Homophylax (nevadensis), } \\
\text { Ironoquia, Neophylax (fuscus), Steno- } \\
\text { phylax (subfasciatus), Zaporota }\end{array}$ \\
\hline $1-2-3$ & Limnephilidæ & $\underset{\text { (ornatus) }}{\text { Anabolina (litha, assimilis), Neophylax }}$ \\
\hline $1-2-4$ & Limnephilidæ & $\begin{array}{l}\text { Anisogamus (antennatus), Apatidea (all } \\
\text { but nigra), Ecclisomyia (all but simu- } \\
\text { lata) }\end{array}$ \\
\hline $1-3-3$ & Limnephilidæ & $\begin{array}{l}\text { Acronopsyche, Drusinus, Glyphopsyche } \\
\text { (ullus), Halesochila, Oligophlebodes, } \\
\text { Platycentropus, Stenophylax (circu- } \\
\text { laris, dan, guttifer) }\end{array}$ \\
\hline \multirow[t]{2}{*}{$1-3-4$} & Limnephilidæ & all genera and species not indicated above \\
\hline & Sericostomatidæ & Neothremma \\
\hline \multirow[t]{3}{*}{$1-4-4$} & Hydropsychidæ & sometimes Hydropsyche \\
\hline & Philopotamidæ & Chimarrhinæ \\
\hline & Sericostomatidæ & Pharula \\
\hline \multirow[t]{2}{*}{$2-2-2$} & Leptoceridæ & Athripsodes, Mystacides \\
\hline & Sericostomatidæ & Micrasema \\
\hline \multirow[t]{2}{*}{$2-2-4$} & Beræidæ & all \\
\hline & Sericostomatidæ & Helicopsyche, Sericostomatinæ \\
\hline $2-3-2$ & Sericostomatidæ & some Brachycentrus \\
\hline $2-3-3$ & Sericostomatidæ & some Brachycentrus \\
\hline $2-4-2$ & Odontoceridæ & some Marilia, some Heteroplectron \\
\hline $2-4-3$ & Odontoceridæ & some Ganonema, some Notiomyia \\
\hline \multirow[t]{8}{*}{$2-4-4$} & Hydropsychidæ & $\begin{array}{l}\text { Arctopsychinæ, Hydropsychinæ except } \\
\text { some Hydropsyche }\end{array}$ \\
\hline & Molannidæ & all \\
\hline & Odontoceridæ & $\begin{array}{l}\text { some Ganonema, some Notiomyia, some } \\
\text { Marilia, some Heteroplectron, all } \\
\text { Namamyia, all Nerophilus }\end{array}$ \\
\hline & Philopotamidæ & Philopotaminæ \\
\hline & Phryganeidæ & all \\
\hline & Psychomyiidæ & Psychomyiinæ \\
\hline & Rhyacophilidæ & Glossosomatinæ, Hydrobiosinæ \\
\hline & Sericostomatidæ & Goera, Pseudogoera, Lepidostomatinæ \\
\hline \multirow[t]{2}{*}{$3-4-4$} & Psychomyiidæ & Polycentropodinæ \\
\hline & Rhyacophilidæ & Rhyacophilinæ \\
\hline
\end{tabular}



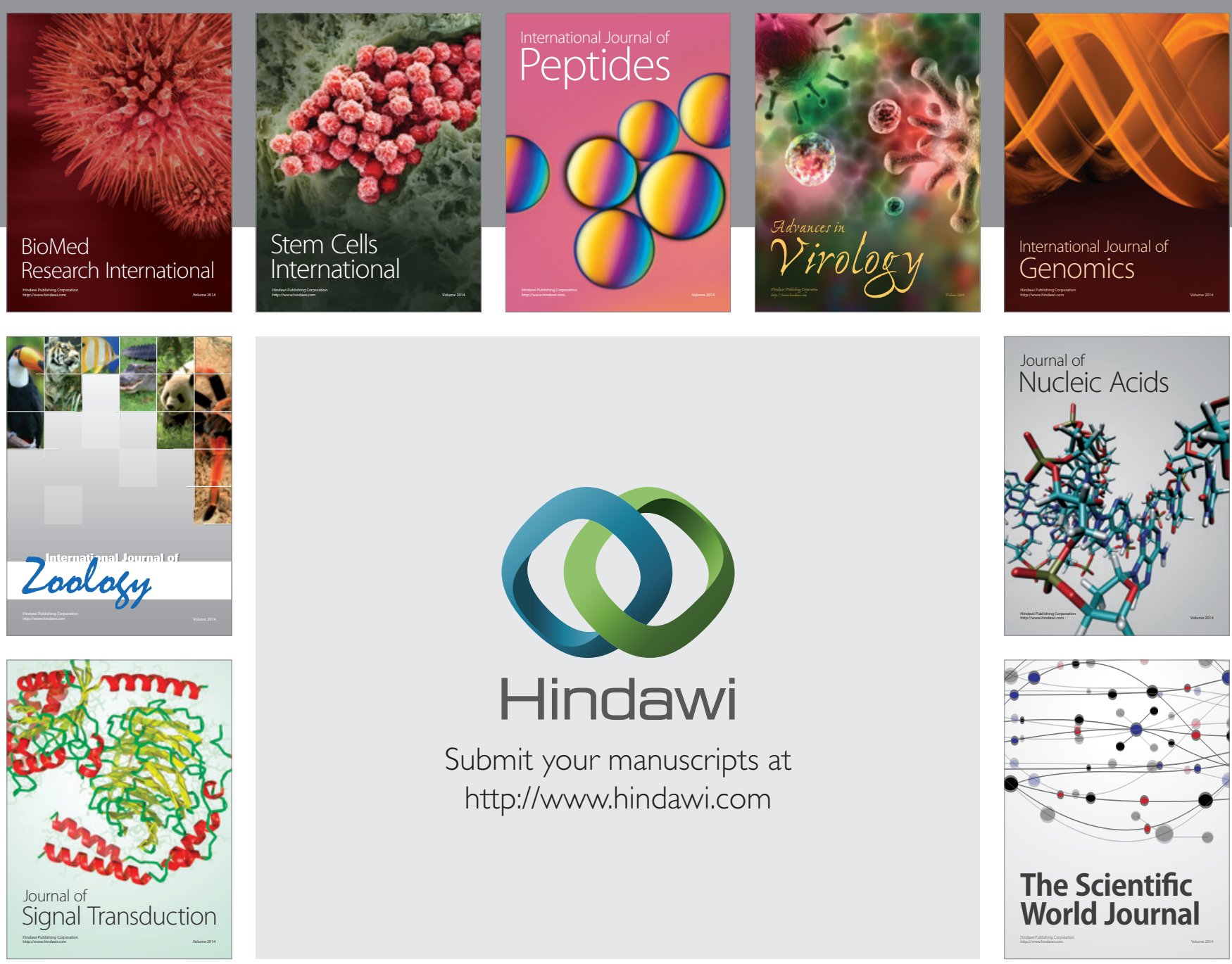

Submit your manuscripts at

http://www.hindawi.com
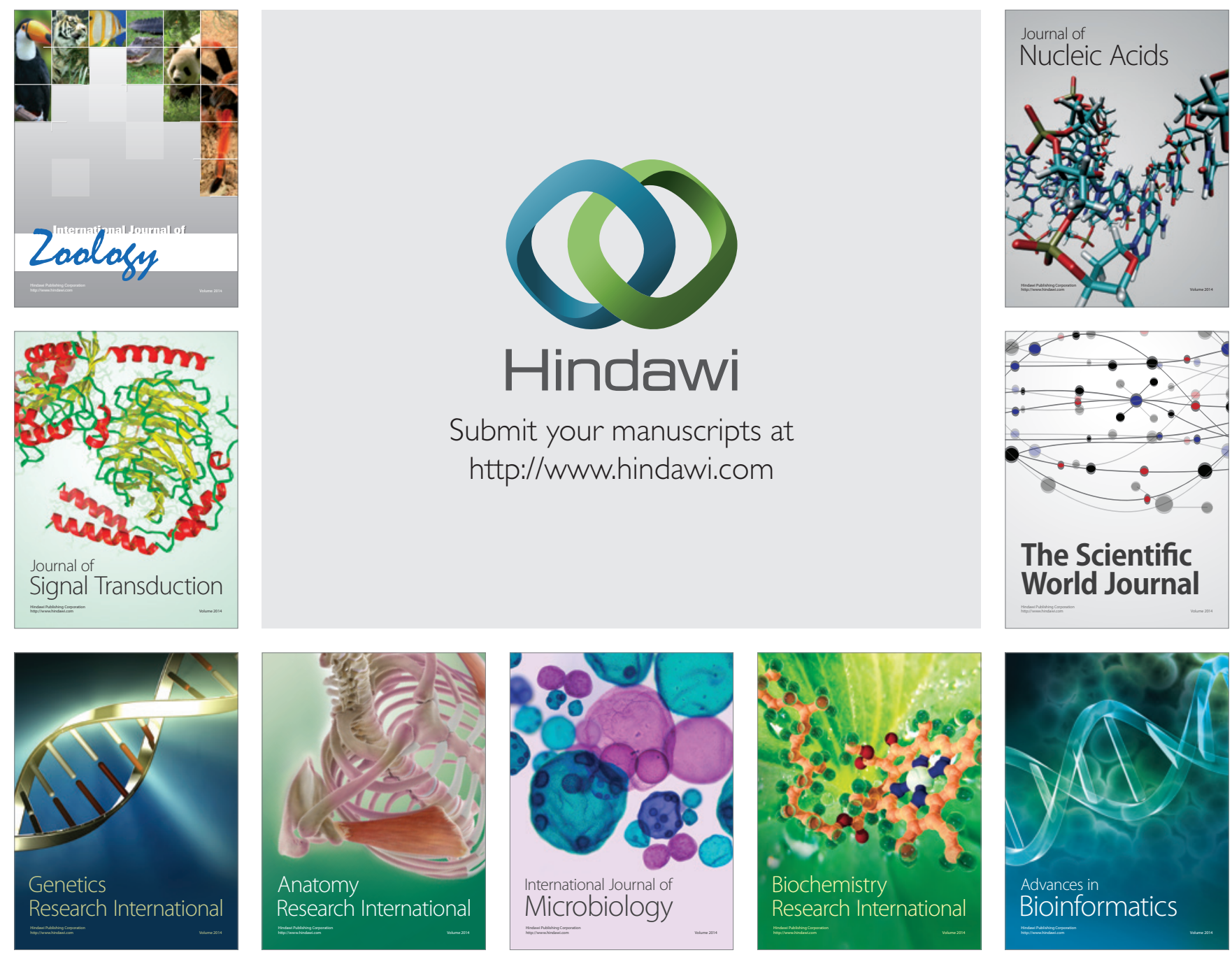

The Scientific World Journal
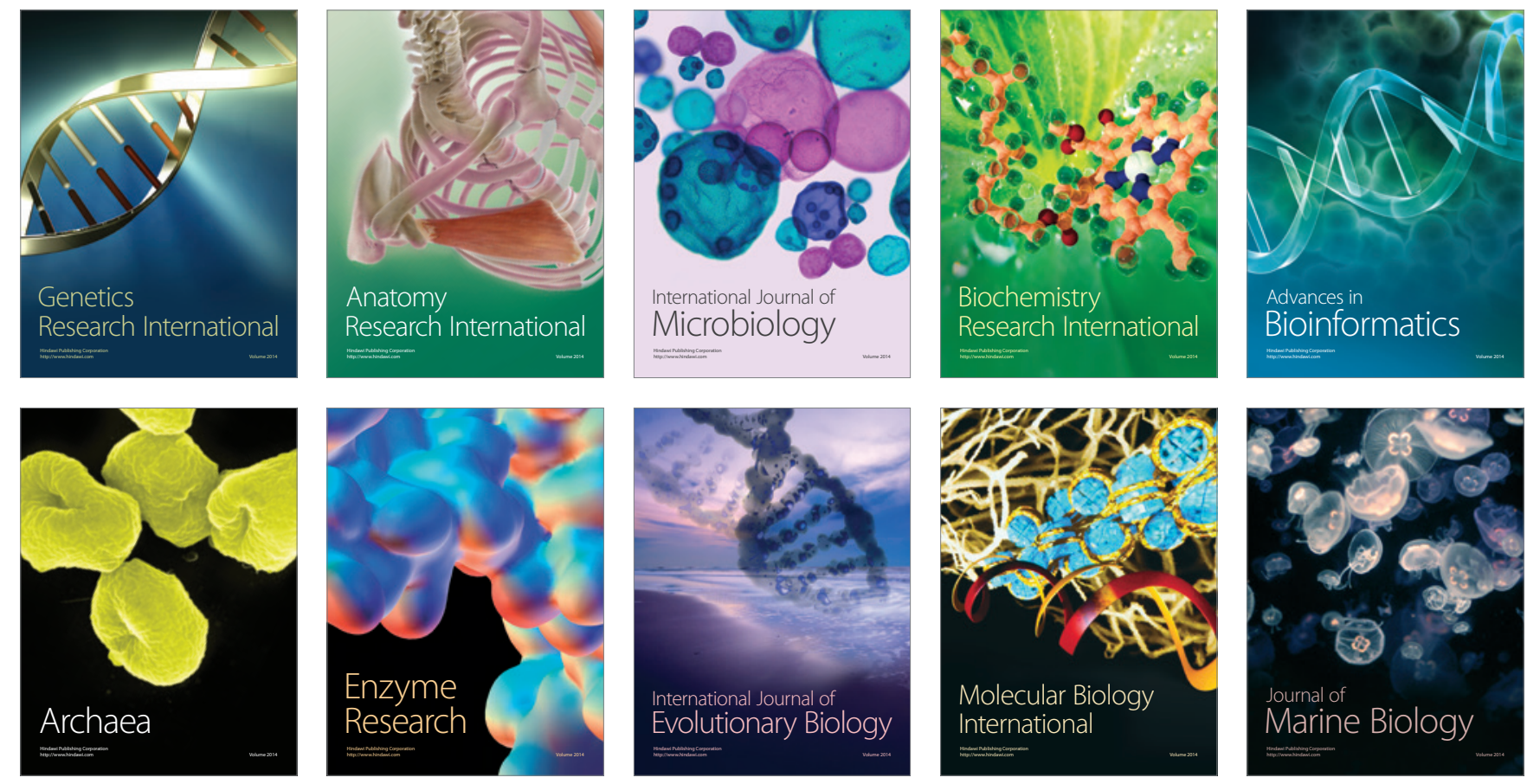